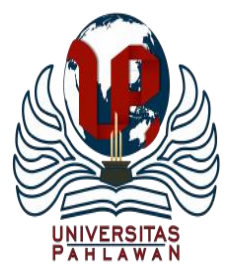

Edukatif : Jurnal Ilmu Pendidikan Volume 3 Nomor 4 Tahun 2021 Halm 2265 - 2270

EDUKATIF: JURNAL ILMU PENDIDIKAN

Research \& Learning in Education

https://edukatif.org/index.php/edukatif/index

\title{
A Qualitative Study: Exploring EFL Students' Attitude Towards Learning Writing during Online Learning COVID-19 in Karawang Senior High School
}

\author{
Anasya Azizah ${ }^{1 凶}$, Sidik Indra Nugraha ${ }^{2}$ \\ Universitas Singaperbangsa Karawang, Indonesia ${ }^{1,2}$ \\ E-mail : anasyaazizah907@ gmail.com ${ }^{1}$, sidik.indranugara@ staff.unsika.ac.id $^{2}$
}

\begin{abstract}
Pada masa wabah Covid-19, mahasiswa dituntut untuk menjalankan proses pembelajaran melalui online, hal ini mempengaruhi sikap mereka dalam pembelajaran, salah satunya pembelajaran menulis. Untuk mengisi celah ini, penelitian ini mengkaji tentang sikap siswa EFL dan unsur-unsur yang mempengaruhi sikap terhadap pembelajaran menulis selama pembelajaran online COVID-19 di SMA Karawang. Penelitian ini menggunakan kualitatif dan data dikumpulkan melalui wawancara semi terstruktur. Empat peserta dari SMAN 4 Karawang diwajibkan mengikuti wawancara secara penuh dalam penelitian. Penelitian ini mengungkapkan bahwa sikap yang ditunjukkan oleh siswa EFL terhadap pembelajaran menulis selama pembelajaran online COVID-19 adalah sikap positif. Siswa menunjukkan minat belajar menulis selama pembelajaran online meskipun siswa lebih memilih untuk belajar menulis dalam pembelajaran tatap muka. Penelitian ini juga mengungkapkan bahwa ada beberapa faktor yang mempengaruhi sikap siswa terhadap pembelajaran menulis selama pembelajaran online COVID-19.
\end{abstract}

Kata kunci: Sikap siswa, Menulis, Belajar Online

\section{Abstract}

During the Covid-19 outbreak, students are required to carry out the online learning process, this affects their attitude in learning, one of which is writing learning. To content this gap, this study examined EFL students' attitudes and the elements that influence the attitudes towards learning writing during online learning COVID-19 in Karawang senior high school. This study used qualitative and data collected through semistructured interviews. Four participants from SMAN 4 Karawang are required to fully participate in the interview. This study revealed that attitudes shown by EFL students towards learning writing during online learning COVID-19 are positive attitudes. The students showed interest in learning writing during online learning although the students more prefer to learn writing in face-to-face learning. This study also revealed that there were some factors that influence students' attitude towards learning writing during online learning COVID-19.

Keywords: Students' attitude, Writing, Online learning

Copyright (c) 2021 Anasya Azizah, Sidik Indra Nugraha

$\triangle$ Corresponding author:

Email : anasyaazizah907@gmail.com

DOI : https://doi.org/10.31004/edukatif.v3i4.1188

ISSN 2656-8063 (Media Cetak)

ISSN 2656-8071 (Media Online)

Edukatif : Jurnal Ilmu Pendidikan Vol 3 No 4 Tahun 2021 p-ISSN 2656-8063 e-ISSN 2656-8071 
2266 A Qualitative Study: Exploring EFL Students' Attitude Towards Learning Writing during Online Learning COVID-19 in Karawang Senior High School - Anasya Azizah, Sidik Indra Nugraha

DOI: https://doi.org/10.31004/edukatif.v3i4.1188

\section{INTRODUCTION}

The COVID-19 pandemic has caused the greatest restriction to many fields around the world, especially in the field of education. According to the United Nations and UNESCO, the closure of schools has impacted 1.6 billion learners ( $94 \%$ of the world's student population) in over 190 countries. Some of these closures started in January, but most began during March (Hussein et al., 2020). This causes the learning process to change, from face-to-face to online learning. According to Rahayu \& Wirza (2020), The Ministry of Education and Culture of Indonesia mentioned that all levels of education will carry out learning at home using online learning due to prevent the spread of COVID-19.

The definition of online learning during the COVID-19 pandemic is described as a learning process where students do not need to come to school to study and teachers do not need to come to school to teaches, they can do those things from home using technology such as a smartphone, tablets, and internet and many platforms such as Google Classroom, Zoom Meeting or Quipper that can be used for online learning (Azhari \& Fajri, 2021; Rahayu \& Wirza, 2020). Furthermore, Jaligama and Liarokapis (2011) explained that the switch of education from face-to-face to online learning is growing fast and technology plays a crucial role, many institutions are trying to make students participate in the online learning environment. Moreover, Jaligama and Liarokapis (2011) also explained that this kind of learning environment can affect students' attitudes differently compared to face-to-face learning.

Writing online learning gives a new atmosphere for students to learn actively. That is shown by students' attitudes that are seen when writing online learning. Attitude is described as a character or propensity to react positively or negatively towards a certain thing such as an idea, object, person, or situation (Hergüner et al., 2020; Hosseini \& Pourmandnia, 2013; Pittam et al., 2009). Hosseini (2013) stated that attitudes have three components which are cognitive, affective, and behavioral. The cognitive component is concerned with the subject of the attitude's beliefs, ideas, or opinions. The affective element is concerned with one's feelings and emotions about an object, such as likes or dislikes, with or against. And for the behavioral component consists of the object's consistent activities or behavioral objectives. Online learning attitude can be described as "the wants and the behavior of the individual towards online learning" (Cinkara \& Bagceci, 2013; Hergüner et al., 2020; Thompson \& Ku, 2005). McKenna, Kear, \& Ellsworth (1995) cited in Graham et al., (2007)., explained that attitude can affect students' skills especially writing skills through some factors, such as cognitive engagement. For instance, students with a positive attitude are more likely to write more frequently and with greater effort when creating than students with a negative attitude, resulting in individual differences in writing goals. Students writing attitude is clarified as an effective control that causes the students to feel happy or unhappy during writing activities (Bulut, 2017).

Nowadays, many ESL students are not interested in writing and have a poor attitude towards writing (Ismail et al., 2012). Concerning ESL students' attitude towards writing, cited from Rein (1993) conclude that one of the most important factors influencing the success of students writing is their interest and attitude towards writing assignments (Ismail et al., 2012). Moreover, Bulut (2017) mentioned that students' interests, desires, attitudes are different for each individual towards learning writing and it can cause their writing achievement. In addition, education, learning environment, and individual characteristics are also considered as factors that influence students' attitudes towards writing. Cited from Nordquist (2009), he explained that whatever students' attitude may be, surely, how students feel about writing both effects and reflects how well students can write (Dayij \& Al.gomoul, 2011; Jabali, 2018; Soomro \& Farooq, 2018). Hence, the quality of their writing is largely determined by how they feel about and react to their writing assignment.

Fageeh (2011) implies in his research that student shows a positive attitude towards the use of weblog. His research argued that students perceive Weblog as a tool for the development of their English, concerning their writing skills and attitudes toward writing, for instance, Weblog giving an opportunity and freedom to 
students for expressing their idea in English, writing for a local and international audience. Moreover, Jaligama \& Liarokapis (2011) explained in their research that the online virtual learning environment is pleasant and possible to be used for the development and delivery of distance learning courses and degrees. While Ismail et al., (2012) in their research entitled 'ESL Students' Attitude, Learning Problems, And Needs for Online Writing' implies that the students have a negative attitude towards writing, they are disliked and careless about it and students find that writing is difficult.

Several studies above which focus on and are connected to the subject of this study have been done before. Despite this, there hasn't been a complete study that focuses on identifying the factors that influence students' attitude of writing skills towards online learning. Most of the previous journals discussed the attitudes shown by students on writing skills towards online learning (Fageeh, 2011; Ismail et al., 2012; Jaligama \& Liarokapis, 2011). Therefore, this study presents what are students' attitudes toward learning writing and also what are the factors that influence students' attitude towards learning writing during online learning covid-19 to helps teachers and student to know further about the attitude and how they resolve it.

\section{METHOD}

This study used a qualitative method conducted by a descriptive case study that provides a detailed, contextualized picture of a particular phenomenon. As cited from Yin (2003) explained that case study is divided into three types considered from the purposes, and one of them is a descriptive case study that aims to provide a detailed, contextualized illustration of a particular phenomenon (Lambert \& Lambert, 2013). Therefore, the case study approach allowed the researcher to study more about students' attitudes of writing skills in English Online Learning during a phenomenon called COVID-19 in detail.

In this research, a qualitative research approach was used by the researcher. Semi-structured interviews as an instrument to gather the data. A semi-structured interview is an outline of questions prepared by the researcher and it has no rigid obedience (Adhabi \& Anozie, 2017). Hence, the implementation of this interview relies on the interviewees' responses to the question laid across by the researcher. Moreover, the researcher adapted the interview question from a study done by Tambunan et al., (2016). The interview consisted of five questions which are; (a) Are you interest in writing? Why? (b) What are the differences that you feel when learning writing through offline class and online class? (c) a. Interest b. Motivation c. Learning environment d. Critical Thinking. From the factors that I mentioned, which are the most affect you in learning writing and why? (d) Do you prefer to learn writing with help from others or by yourself? Why? And (e) If those factors interfere with you, how do you resolve it? The participants of this study were four students from SMAN 4 Karawang. All participants are required to do a semi-structured interview with the researcher. The interview spent 10-15 minutes and it is done via video call from zoom meeting to prevent the virus COVID-19 and follow the rules from the government,

Following the interview, the data was examined using some identification and familiarization techniques. It's critical that you comprehend the facts to the point where you're comfortable with the interview's depth and breadth, and that you maintain re-listening to the original audio recordings to ensure their authenticity (Braun et al., 2008). Moreover, the transcription procedure would be time-consuming, annoying, and wasteful, thus this is the only viable option. After the interview was conducted, the data obtained is analyzed using thematic analysis. Thematic analysis is described as a technique for systematically discovering, organizing, and analyzing patterns of themes in a data set (Braun \& Clarke, 2012). Braun \& Clarke (2012) also mentioned that with thematic analysis, the researcher can verify one particular aspect of a phenomenon's depth. There are six stages in thematic analysis, including familiarizing, generating, searching, reviewing, defining and naming, producing. 
2268 A Qualitative Study: Exploring EFL Students' Attitude Towards Learning Writing during Online Learning COVID-19 in Karawang Senior High School - Anasya Azizah, Sidik Indra Nugraha

DOI: https://doi.org/10.31004/edukatif.v3i4.1188

\section{RESULT AND DISCUSSION}

The result was obtained through interview. There are some general pattern findings of this study. (1) The EFL students' attitude towards learning writing during online learning COVID-19. (2) Factors that influences the EFL students' attitude towards learning writing during online learning COVID-19.

\section{The EFL students' attitude towards learning writing during online learning COVID-19}

Students showed various attitudes towards learning writing during online learning COVID-19. The explanation from the students will be found out as students' vignette 1,2,3, and 4 .

Students' Vignette 1

I interest learning writing because it has the differences when I speak and write but it makes me interest learning writing. (\#1)

Students' Vignette 2

I am not too interest in learning writing, because sometimes I always make a mistake when I write in English. I have limitations to write. (\#2)

Students' Vignette 3

I feel interest to write in Indonesia but still learn to write English. (\#3)

Students' Vignette 4

I think writing makes me interest because I have some difficulties before I write. Writing English is quite challenges for me. (\#4)

Based on mentioned interview transcription, it is clearly stated that students show various attitudes in learning writing during online learning. It means some of the students show positive attitudes towards learning writing which includes the affective domain where students' interest plays a crucial role in their attitude in learning writing during online learning. Moreover, some of the students think that writing gives challenges to them thus makes the students interested in learning writing. Meanwhile, another answer from the students showed that she is not too interested in learning writing during online learning. It means she showed negative attitudes towards learning writing that can affect her achievement in writing. Those results are in line with a statement from Dayij \& Al.gomoul, (2011) that explained both positive and negative, it will all affect student success in learning.

\section{Factors that influence the EFL students' attitude towards learning writing during online learning COVID-19.}

There are some factors that influence students' attitude in learning writing that found in the interview which are; interest, learning environment, and critical thinking. Those reinforced by the data that obtained from the interview as follow as Students' Vignette 1,2,3,4.

Students' vignette 1 and 3

Factors that the most influence me in learning writing is interest. Because I really want to learn English and it makes me interest in learning English especially writing, because I personally still needs some guidance from teacher in learning writing. (\#1)

Interest, because when I start to learning writing, I need to like it first or in the condition where I have a good mood, so it can help me writing well. (\#3)

Students' vignette 2

Learning environment really affect me in learning writing, especially during online learning. I prefer to learning offline because the vibe of the learning is different compared to the online learning. (\#2)

Students' vignette 4 
2269 A Qualitative Study: Exploring EFL Students' Attitude Towards Learning Writing during Online Learning COVID-19 in Karawang Senior High School - Anasya Azizah, Sidik Indra Nugraha

DOI: https://doi.org/10.31004/edukatif.v3i4.1188

For learning writing, I always lacks of critical thinking, sometimes I run out of ideas and topics to write, I think it affect me the most when start learning writing. (\#4)

Based on mentioned interview transcription, it is clearly found that there are various factors that influence students' attitudes towards learning writing. The first factor that found is interest. It is in line with the statement from Hosseini \& Pourmandnia (2013) that interest itself is considered as an effective factor that focusing on the emotion of a subject towards something. The second factor that is found is the learning environment. The learning environment is one of the factors that can affect students' attitude toward achieving learning goals, especially in learning writing. It is in line with the statement from Bulut (2017) that the learning environment can affect how students feel in learning. Those results were also reinforced by students' answers from the interview which asks about "Do you prefer to learn writing with help from others or by yourself? Why?". The summary of the students' answers explained that students prefer to learn writing through face-to-face learning or offline learning compared to online learning because they can discuss with their partners or can asks help from the teacher about the learning while online learning have to work on their own self without any help from the others, only from books or internet helps. The last factor that is found is critical thinking. Critical thinking is considered a cognitive factor that is emphasized in aspects of knowledge and reasoning. As stated by Hosseini \& Pourmandnia (2013) that cognitive emphasizes mastering knowledge in achieving learning goals. Moreover, students also answered that they have solutions to resolve those factors above, among others, are reading from other sources such as books or internets or having a discussion with the other students.

The students have some positive and negative effects in learning writing. From the data transcription interview, it is clear that this study fills the gap from the previous study which resulted from students show both positive and negative attitudes towards learning writing, while this study resulted that student shows mostly enthusiastic attitudes towards learning in the new conditions to COVID-19 and found some factors that influence the attitudes shown by students during learning writing in online learning COVID-19 condition.

\section{CONCLUSION}

The findings of this study were discovered from four students of SMAN 4 Karawang as the respondent to give their opinion and reaction based on their experiences in learning writing during online learning COVID-19. Based on the findings and discussion of the research, it could be concluded that (1) Students' attitudes towards learning writing during online learning COVID-19 are mostly positive attitudes and (2) Factors that influence students' attitude towards learning writing during COVID-19 mostly are because interest, learning environment and lacks critical thinking. It is suitable with the aims of this research that find EFL students' attitudes towards learning writing during online learning COVID-19.

\section{REFERENCES}

Adhabi, E. A. R., \& Anozie, C. B. L. (2017). Literature Review for the Type of Interview in Qualitative Research. International Journal of Education, 9(3), 86. https://doi.org/10.5296/ije.v9i3.11483

Azhari, B., \& Fajri, I. (2021). Distance learning during the COVID-19 pandemic: School closure in Indonesia. International Journal of Mathematical Education in Science and Technology, February. https://doi.org/10.1080/0020739X.2021.1875072

Braun, V., \& Clarke, V. (2012). Thematic Analysis Thematic Analysis , p . 2. 2, 57-71.

Braun, V., Clarke, V., Braun, V., \& Clarke, V. (2008). Using thematic analysis in psychology Using thematic analysis in psychology. 0887(2006).

Bulut, P. (2017). The effect of primary school students' writing attitudes and writing self-efficacy beliefs on their summary writing achievement. International Electronic Journal of Elementary Education, 10(2), 
2270 A Qualitative Study: Exploring EFL Students' Attitude Towards Learning Writing during Online Learning COVID-19 in Karawang Senior High School - Anasya Azizah, Sidik Indra Nugraha DOI: https://doi.org/10.31004/edukatif.v3i4.1188

281-285. https://doi.org/10.26822/iejee.2017236123

Cinkara, E., \& Bagceci, B. (2013). Learners' attitudes towards online language learning; and corresponding success rates. Turkish Online Journal of Distance Education, 14(2), 118-130. https://doi.org/10.17718/tojde.82980

Dayij, M., \& Al.gomoul, S. (2011). Teaching and Assessing Writing Strategies for Secondary School Students and Investigating Teachers' and Students' Attitudes towards Writing Practice. International Journal of Educational Sciences, 3(1), 25-36. https://doi.org/10.1080/09751122.2011.11890006

Fageeh, A. I. (2011). EFL learners' use of blogging for developing writing skills and enhancing attitudes towards English learning: An exploratory study. Journal of Language and Literature, 2(1), 31-48.

Graham, S., Berninger, V., \& Fan, W. (2007). The structural relationship between writing attitude and writing achievement in first and third grade students. Contemporary Educational Psychology, 32(3), 516-536. https://doi.org/10.1016/j.cedpsych.2007.01.002

Hergüner, G., Buğra SON, S., Hergüner Son, S., \& Dönmez, A. (2020). The effect of online leearning attitudes of university Students on their Online Learning Readiness. TOJET: The Turkish Online Journal of Educational Technology, 19(4), 102-111.

Hosseini, S., \& Pourmandnia, D. (2013). Language Learners'Attitudes and Beliefs: Brief Review of the Related Literature and Frameworks. International Journal on New Trends in Education and Their Implications, 4(4), 63-74. http://www.ijonte.org/FileUpload/ks63207/File/2013ijonte.4.pdf\#page=70

Hussein, E., Daoud, S., Alrabaiah, H., \& Badawi, R. (2020). Exploring undergraduate students' attitudes towards emergency online learning during COVID-19: A case from the UAE. Children and Youth Services Review, 119(November), 105699. https://doi.org/10.1016/j.childyouth.2020.105699

Ismail, N., Hussin, S., \& Darus, S. (2012). ESL students' attitude, learning problems, and needs for online writing. GEMA Online Journal of Language Studies, 12(4), 1089-1107.

Jabali, O. (2018). Students' attitudes towards EFL university writing: A case study at An-Najah National University, Palestine. Heliyon, 4(11), e00896. https://doi.org/10.1016/j.heliyon.2018.e00896

Jaligama, V., \& Liarokapis, F. (2011). An online virtual learning environment for higher education. Proceedings - $20113 \mathrm{rd}$ International Conferenceon Games and Virtual Worlds for Serious Applications, VS-Games 2011, 207-214. https://doi.org/10.1109/VS-GAMES.2011.44

Lambert, V. a., \& Lambert, C. E. (2013). Qualitative Descriptive Research: An Acceptable Design. Pacific Rim International Journal of Nursing Research, 16(4), 255-256. http://antispam.kmutt.ac.th/index.php/PRIJNR/article/download/5805/5064

Pittam, G., Elander, J., Lusher, J., Fox, P., \& Payne, N. (2009). Student beliefs and attitudes about authorial identity in academic writing. Studies in Higher Education, 34(2), 153-170. https://doi.org/10.1080/03075070802528270

Rahayu, R. P., \& Wirza, Y. (2020). Teachers' Perception of Online Learning during Pandemic Covid-19. Jurnal Penelitian Pendidikan, 20(3), 392-406. https://doi.org/10.17509/jpp.v20i3.29226

Soomro, A. F., \& Farooq, M. U. (2018). EFL Learners' Attitude towards Developing Speaking Skills at the University of Taif, Saudi Arabia. International Journal of English Linguistics, 8(3), 318. https://doi.org/10.5539/ijel.v8n3p318

Tambunan, E. R., Sutapa, , Gatot, \& Susilowati, E. (2016). the Attitude Towards Speaking English. Jurnal Pendidikan Dan Pembelajaran, 5(11), 1-11.

Thompson, L., \& Ku, H. Y. (2005). Chinese graduate students' experiences and attitudes toward online learning. Educational Media International, 42(1), 33-47. https://doi.org/10.1080/09523980500116878 